\title{
CERCETAREA MATERIALELOR DOCUMENTELOR. SARCINI ŞI METODE DE CERCETARE A MATERIALELOR DOCUMENTELOR CU SCOPUL DETERMINĂRII TIMPULUI CREĂRII DOCUMENTELOR
}

DOI:10.24193/SUBBiur.62(2017).2.3

Published Online: 2017-06-15

Published Print: 2017-06-30

\section{Alina ZADOROJNIUC}

Abstract: Materials research document. Tasks and methods of research on materials of documents with of determining time of created. The determination of time in execution of documents is an important parameter in determining the authenticity of documents. In present work are presented several methods of documents dating written with different writing materials, which involves determination of different parameters, which may change over time: reaction speed; solubility; concentrations of volatile substances, etc.

Keywords: documents; issuing; forensic determination.

\section{ACTUALITATEA TEMEI}

Inventarea scrisului reprezintă o etapă importantă în istoria dezvoltării omenirii. Documentele au o însemnătate deosebită şi se utilizează în toate domeniile de activitate, datorită acestui fapt în practica judiciară apare tot mai frecvent necesitatea cercetării documentelor ce prezintă suspiciuni privind autenticitatea lor, precum şi a posibililor falsificări a acestora.

Dezvoltarea continuă a ştiinţei şi tehnicii a contribuit la faptul că numărul documentelor falsificate să fie în creştere şi de o calitate mai ridicată, acestea fiind tot mai greu de depistat şi de deosebit de actele originale.

În prezent există o multitudine de metode de cercetare a materialelor documentelor, printre care fac parte: metode chimice (cercetarea materialelor cu ajutorul reacţiei de picurare; cercetarea compoziţiei elementare; ş.a.); metode fizico-chimice (spectroscopia IR; cromatografia în strat subţire; analiza spectrală de emisie/absorbţie; ş.a.); metode microscopice; ş.a.[4]

O atenţie deosebită se acordă determinării timpului îndeplinirii documentului, în acest domeniu fiind efectuate o multitudine de cercetări.

\section{OBIECTIVE}

1. Studiul metodelor de cercetare a materialelor documentelor cu scopul depistării falsului; 
2. Analiza detaliată a metodelor de cercetare a materialelor documentelor cu scopul determinării timpului creării;

\section{ANALIZE, CONSTATĂRI}

În cadrul cercetării materialelor documentelor se pot diviza următoarele sub-domenii:

- cercetarea hârtiei şi cartonului;

- cercetarea conţinutului instrumentelor scripturale (cerneală, pastă, minele creioanelor, ş.a.);

- cercetarea materialelor scripturale destinate obţinerii impresiunilor şi a materialelor utilizate pentru multiplicare-copiere (vopsele pentru ştampile, tonere, cerneală pentru imprimante jet, ş.a.);

- cercetarea cleiului;

- cercetarea materialelor de copertare;

- cercetarea substanţelor corosive.

Fiecare întrebare formulată expertului spre soluţionare se abordează în mod special în dependenţă de materialul destinat cercetării.

Una dintre cele mai frecvente întrebări adresate expertului este determinarea timpului efectuării înscrisului, acesta fiind un indicator important în stabilirea autenticităţii documentului.

În prezent există o multitudine de cercetări în domeniul dat, materialele de scriere sunt cercetate atât sub aspectul compoziţiei calitative a lor, cât şi a transformărilor pe care le suferă substanţele înglobate ca urmare a acţiunii timpului, sau a condiţiilor de mediu în care au fost păstrate actele.

Datorită compoziţiei calitative şi cantitative a materialelor de scriere, acestea sunt bine diferenţiate în: hârtie; creioane; cerneală de diferite tipuri; pasta pentru stilou cu bilă; hârtia copiativă; vopsea pentru ştampile; tonere, cerneală pentru imprimante jet, ş.a.

Datarea actelor scrise cu creionul din punct de vedere chimic este dificilă, deoarece trecerea timpului nu influentează semnificativ stabilitatea substanţelor care intră în compoziţia minei. Textele scrise cu creion copiativ/ colorat sunt de dată mai recentă decât cele executate cu creion obişnuit. Identificarea colorantului din traşeele grafice executate cu creionul copiativ/ colorat permite limitarea perioadei de timp în care au fost redactate actele.

Datarea actelor scrise cu cerneală: Presupune mai multe modalităţi de cercetare, care cuprind determinarea diferitor parametri dependenţi de vechimea înscrisurilor:

- Cerneala carbon a fost utilizată multă vreme la scriere, datarea fiind greu de rezolvat. Cerneala suferă puţine modificări în timp, singura schimbare este nuanţa, pentru datare se cercetează coloranţii utilizaţi pentru corectarea nuanţei de cafeniu specifică carbonului, precum şi a lianţilor deoarece aceştia au fost folosiţi în procesul de fabricaţie a cernelii la date precis determinate.

- Cerneala pe bază de galatonat de fier, cerneala proaspătă are culoarea temporară specifică colorantului ce intră în compoziţia ei, iar odată cu trecerea timpului în urma 
proceselor de oxidare, în decurs de aproximativ doi ani devine neagră şi mult mai stabilă la acţiunea factorilor mediului. Este posibilă îngălbenirea cerneliii odată cu trecerea timpului datorită procesului de descompunere a coloranţilor şi a compuşilor fierului, însă toate modificările suferite de cerneală nu sunt uniforme, ci depind mult de condiţile de păstrare precum şi calitatea materialului pe care a fost efectuat înscrisul. [1]

* Analiza solubilităţii cernelii. La actele redactate recent, la acţiunea apei cerneala se scurge şi pătează mult suportul, iar la acţiunea timpului solubilitatea componentelor cernelei se reduce considerabil, dizolvabil rămânând doar colorantul care, se desprinde din compuşii insolubili de fier în care este integrat. Stabilirea gradului de solubilitate se face prin tratarea actelor cu soluţii acide cu concentraţie de $5 \%$ (soluţii ale acidului oxalic sau clorhidric). Solubilitatea este influenţată de condiţiile în care a fost păstrat documentul, iar determinarea timpului se face numai la examinarea comparativă a înscrisurilor executate cu aceeaşi cerneală, cu condiţia că ele au fost păstrate în aceleaşi condiţii ca şi documentele litigioase.[1, 2]

* Analiza gradului de migrare în masa de hârtie a componentelor de clor şi sulf din cerneală, pentru clor durează aproximativ 2 ani, în timp ce a sulfaţilor -depăşeşte 10 ani. Umiditatea crescută influenţează gradul de migrare, metoda dată poate fi utilizată doar cu condiţia că materialele supuse cercetării pe parcursul timpului nu au fost supuse acţiunii umedităţii ridicate.

În prezent se utilizează analize gaz-cromatografice, specrometria de masă şi cromatografia densiometrică în strat subţire.

Cea mai eficientă metodă de stabilire a vechimii unui înscris se bazează pe cromatografia gazoasă şi spectrometria de masă, iar reziduurile agenţilor cernelii sunt examinate împreună cu solvenţii. Cu ajutorul acestor metode se pot data majoritatea cernelurilor, pastelor de scris ca şi tuşurile tipografice.

Alte categorii de examinari care sunt efectuate cu scopul stabilirii vechimii documentelor scrise cu cerneală, este stabilirea gradului de copiabilitate. [4]

* Gradul de copiabilitate se poate determina prin punerea actului scris în contact direct cu partea gelatinoasă a unei hârtii fotografice, din emulsia căreia au fost îndepărtate halogenurile de argint prin tratarea într-o baie de fixator. Cerneala va adera la hârtia fotografică într-o masură mai mare sau mai mică, în raport cu vechimea actului, gradul de aderenţă descrescând odată cu scurgerea timpului.

* Viteza de reacţie a cernelii la tratarea cu diverşi reactivi scade odată cu trecerea timpului, cerneala veche având o reacţie mai lentă decât cea proaspătă. În calitate de reactiv se foloseşte un agent oxidant în soluţii diluate de perhidrol sau clorură de var. Cerneala cu o vechime de câteva zile, dacă este tratată în clorură de var dispare în 6 minute, cea de 6 luni în 9-12 minute, iar cea veche de 1 an- în 20 minute. Trăsăturile cu o vechime de 2 ani dispar parţial, cele de 14 ani sunt uşor afectate, iar cele mai vechi de 22 ani nu se modifică deloc în primele 20 minute de interacţionare cu reactivi. Datele obţinute sunt doar orientative, procedeul poate fi folosit pentru orice tip de cerneală, indiferent de condiţiile de executare şi păstrare a documentului.

Datarea actelor scrise cu cerneala stiloului cu bilă este deosebit de dificilă, deoarece pasta se decolorează sub acţiunea luminii solare directe (îndeosebi cernelurile 
verzi şi roşii) iar unele dintre ele dispar complet. În cazul falsului prin adăugare de text, dacă cercetarea se desfăşoară într-un moment nu prea îndepărtat de cel al executării scrisului, se pot constata că scrisul preexistent este decolorat iar adăugirile au o culoare mult mai pronunţată, locurile în care sunt prezente putând fi identificate relativ uşor.

Cernelurile actuale au o rezistenţă foarte mare la decolorare, iar stabilirea vechimii relative a paragrafelor dintr-un act scris este cu mult mai greu de determinat. Pentru datarea actelor se utilizează metode ce constau în cercetarea comparativă a conţinutului de substanţe volatile remanente în urmele de cerneală în actul în litigiu şi probele de comparaţie efectuate cu aceeaşi cerneală în perioade apropiate de timp (perioada de timp specificată de expert) cu ajutorul cromatografiei lichide. Cromatograful trebuie să ofere posibilitatea de a introduce proba cercetată fără dizolvare în interiorul tubului de injectare, cu scopul transferului cantitativ a substanţelor volatile.

Documentele redactate cu stilou cu bilă nu pot avea o vechime anterioară anului 1946, an în care a fost produs şi comercializat pentru prima dată un asemenea instrument de scris.

Datarea actelor scrise cu pasta de tip gel în prezent nu s-au elaborat metodici care ar permite datarea acestora, deoarece gelul posedă proprietăţi deosebite faţă de alte materiale de scris, şi datarea lui poate fi efectuată pentru o perioadă foarte mică care de obicei nu este reprezentativă (aroximativ o lună).

Determinarea vechimii prin examinarea hârtiei pe care este depus scrisul.

Stabilirii sortului de hârtie permite obţinerea unor informaţii importante despre vechimea maximă a documentelor, îndeosebi atunci când se pretinde ca ele sunt foarte vechi. Hârtia se cercetează sub aspectul constituenţilor săi, avându-se în vedere natura fibrelor, materialelor de umplere şi de încleiere, a coloranţilor, tratamentul aplicat la suprafaţa ei etc.

Atunci când obiectul examinărilor îl constituie documente contemporane, cercetarea naturii hârtiei oferă un număr restrâns de informaţii pentru datare, deoarece principiile de bază şi tehnicile de fabricare au rămas, cu mici excepţii, neschimbate încă din a doua jumătate a secolului al XIX-lea.

Pentru stabilirea unei perioade de timp bine determinate cercetarea hârtiei nu prezintă o informaţie precisă ci doar vechimea maximă cînd s-a produs hîrtia, însă înscrisurile pot fi efectuate cu o perioadă mult mai tîrzie decât data fabricării acesteia. Din aceste considerente determinarea vechimii hîrtiei se efectuează doar în măsură de a determina vechimea maximă când ar putea fi efectuat înscrisul.

\section{CONCLUZIE}

Din toate cele relatate mai sus se poate concluziona:

Determinarea perioadei relative de efectuare a înscrisurilor are loc prin compararea anumitor parametri caracteristici pentru fiecare material de scris în parte ai documentului în litigiu cu cei a altor acte puse la dispoziţia expertului pentru comparaţie.

Pentru actele supuse condiţiilor de mediu extreme, precum şi factorilor de îmbătrânire artificială este greu sau chiar imposibil de determinat timpul îndeplinirii înscrisurilor. 


\section{BIBLIOGRAFIE}

1. E. Locard - Les faux en écriture et leur expertise - Editure Payot, Paris, 1959, pag. 345

2. V. Bercheşan, M. Ruiu, "Tratat de tehnică criminalistică“- Editura Little star, Bucureşti 2004, pag. 536

3. В.С. Митричев , В. Н. Хрусталёв „Основы криминалистического исследования материалов, веществ и изделий из них", Moscova- 1964

4. С.М. Соколов, В. Н. Хрусталёв, „Судебнохимическая экспертиза материалов документов, копоти выстрела, волокнистых веществ и других вещественных доказательств", (Методическое пособие для экспертов), Питер- 2003

* CNEJ MJ, mun. Chişinău, Republica Moldova 